\title{
Coconut Palms on the Edge of the Desert: Genetic Diversity of Cocos nucifera L. in Oman
}

\author{
Lalith Perera $^{1}$, Luc Baudouin ${ }^{2}$, Roland Bourdeix ${ }^{3}$, Anwar Bait Fadhil ${ }^{4}$, \\ Fabien C.C. Hountondji ${ }^{4}$ and Abdulaziz Al-Shanfri ${ }^{4}$
}

\begin{abstract}
In the Gulf region, coconuts are almost exclusively produced from palms growing in the Sultanate of Oman, particularly in the extreme south-eastern coastal plain of the Dhofar Governorate, and specifically within the city limits of Salalah, between the Jebel and the sea. The importance of these coconuts is not only agricultural; historically, the Dhofar palms provided the basic materials to build boats for fishermen and traders on, around and eventually beyond the Indian Ocean. Coconut palms are now one of the main symbols of Salalah city and play a role in both the tourist industry and urban landscaping. In early 2009, twenty-nine sites, representing Oman coconuts on beaches and cultivated lands were chosen from the Dhofar region. COGENT descriptors and DNA analysis were used for the purpose of identifying coconut germplasm available in Oman. The presence was confirmed of varieties that were imported during the 1980s, such as Yellow Dwarf, Green Dwarf and King coconut from Sri Lanka, as well as Malayan Yellow Dwarf and F1 hybrids. The local Oman Tall has the same phenotypic characteristics as other coconuts of South Asia, East and West Africa, the Caribbean and the Atlantic coast of South America. Microsatellite markers, however, reveal a substantial genetic contribution of the South-East Asian coconuts, at levels that are comparable to those found in the Comoros and Madagascar coconuts. Hypotheses about the ancestry of the Oman Tall coconuts are discussed; two genepools are indicated, consecutively involving natural selection, dissemination by floating, domestic selection and dispersal by boat.
\end{abstract}

Keywords: coconut, conservation, Dhofar, genetic resources, Oman, Salalah

1. Genetics and Plant Breeding Division, Coconut Research Institute, Lunuwila, Sri Lanka.

2. CIRAD (UPR étiologie dépérissements), France.

3. CIRAD (CEFE Centre d'Ecologie Fonctionnelle et Evolutive), Bioversity Int. Honorary Fellow, France.

4. Ministry of Agriculture, Directorate General of Agricultural and Livestock Research, Salalah Agricultural Research Station. P.O. Box 1286, 211, Salalah, Sultanate of Oman.

Corresponding Author: Lalith Perera; E-mail: lalithperera1234@yahoo.com, Phone: 0094713127954,

Fax: 0094312258391 


\section{Introduction}

In the Gulf region, coconut is almost exclusively grown and produced in the Sultanate of Oman, particularly in the coastal plain of the Dhofar Governorate located in the south-east of Oman. Coconut palms are seldom found in most other coastal places of Oman, and when present are grown for ornamental purposes and fruits are almost absent. Coconut palms have been known in Dhofar for many centuries and along the coastal plain of the Arabian Sea towards Yemen, in particular locations where climatic, soil and water condition are especially favourable for coconut cultivation (Shammas and Jacks 2008). The use of coconut fibres to assemble the planks of ships instead of nails, once widespread around the Indian Ocean, has remained in use in Oman until recently (Vosmer 1997).

In the last 20 years, the coconut palm has become the symbol of the city of Salalah. Coconut palms are pictured in many tourist documents of the city indicating that the importance of the coconut palm in Oman is not only agricultural. In environmental, cultural and tourism terms, the coconut palm has become an integral part of the identity of the Dhofar region. While coconut palms remain mainly confined to a role of creating an atmosphere, they could even more effectively highlight the special features of the local culture and ecology within an eco touristic approach.

The coconut cultivation covers about 463 hectares of which $75 \%$ is produced in agricultural holdings and the remaining as private and public gardens (Oman Ministry of Agriculture and Fisheries Report 2006). Annual production was estimated around 14,000 tons fresh nuts (Al Shanfari and Abdulrahman, unpublished data). Coconut is grown in mono-cropping or intercropping patterns, with mainly vegetables and fruit trees in the peri-urban areas, in isolated sites between the city and the mountain, and at the feet of the mountains.

Coconut farms are generally contracted to expatriates for mangement, mainly from India, Bangladesh and Pakistan. It is also especially noticeable that, with the developments in the tourist industry in Oman, coconut has recently become an economically important crop for its fresh tender-nuts as a natural health drink. Therefore immature coconut for drinking is the main harvest, while the other uses of mature coconut, such as oil, from copra, for cosmetic and culinary purposes is negligible in Oman. The harvest is both sold locally and exported to the Gulf region, mainly to the United Arab Emirates.

Relatively few varieties of coconut were observed to be grown in Oman. Several types commonly recognized as belonging to local varieties by their tall height, prevalence and their long-term presence appear to constitute the majority of the varieties in Oman. Other varieties, which seem to be more recent and are qualified as exotic, are present but with limited distribution. Most of these exotic varieties are known to have been introduced from Sri Lanka and to a lesser extent from Malaysia two to three decades ago. Knowledge about the coconut germplasm present in Oman is limited to these preliminary accounts. Recently, identification of the coconut germplasm was initiated by the Oman Ministry of Agriculture. This paper reports on the on-going efforts towards the identification and characterization of Oman coconut germplasm.

\section{Materials and Methods}

We surveyed 29 of the 30 sites selected for seasonal surveys for the coconut mite Aceria guerreronis Keifer. These sites are representative of the majority of the Oman coconut growing areas inland, at the foot of the Jebel and on the coast. Within these sites, varieties grown were inspected, observed and identified visually. We also harvested coconuts in the local Tall populations, especially those located near the beach which were prepared and photographed to show the morphological diversity in size, shape and colour. Fruit Component Analyses (FCA) data were recorded on a total of 175 palms from 25 sites (Table 1) according to the COGENT standard techniques (Santos et al. 1996). We also performed analysis of DNA using molecular markers in order to characterize the local variety and to confirm the putative origin of imported varieties. The 14 
SSR primers in the IPGRI-COGENT micro satellite kit for coconut molecular analysis (Baudouin and Lebrun 2002), were used (for technical details see Martinez et al. 2010).

\section{Results}

\section{Local Tall}

Most of the Oman coconuts were planted in Salalah Township (southern part of the town), Razat Farm and Taqah. Scattered coconut palms were also found in the region from Rakhyut in the west to Marbat in the east and Qayrum Hayritt to the north. The traditional Oman Tall populations constituted the majority of the varieties in Oman. They were present in large proportion (more than 90\%) compared to introduced varieties in most of the surveyed sites. Some sites were exclusively grown to local tall from seedlings raised from old plantations. It was estimated that $80 \%$ of the nearly 200,000 coconut palms in Oman were less than 40 years old. A few coconut palms were less than 10 years old, mainly in the area close to the mountains and near the beach.

The whole fruit weight and its component varied considerably within sites as well as among sites: mean values ranged from 794 to 2740 for fruit weight. Husk/fruit and mesocarp/nut and water/nut ratios were correlated with fruit weight ( $\mathrm{r}$ equal to $+0.805,-0.855$ and +0.835 respectively). Such variation is not unexpected given the considerable differences among sites for several environmental factors: level of the water table, degree of salinity, irrigation and the incidence of a major pest, the eriophyid mite Aceria guerreronis Keifer (Al-Seigh, Al-Shanfari and Hountondji, unpublished data). Mite damage interferes with the characteristics of the nut. Very large coconut mite populations complete their life cycles (from egg to adult), concealed beneath the calyx of the young developing fruit. They attack the meristematic tissue and the damage caused by feeding results in development of surface scars that enlarge and dry out as the fruit expands (Moore et al. 1989; Julia and Mariau 1979; Mariau 1977; Sathiamma et al. 1998; Fernando et al. 2000). Early infestations result in smaller fruits with the badly scarred husk becoming crevassed. Such fruits were excluded from the sample taken for FCA. In the Dhofar region, surveys conducted during different seasons from 2008 to 2009 revealed nearly $100 \%$ incidence of the coconut mite among coconut palms, with $82 \%$ of the nuts attacked. However average nut damaged by the mite is below $25 \%$ of the area of the nut (Al-shanfari and Houtondji, unpublished results). The mite is also a serious pest in Africa and in America (Mariau 1977; Sathiamma et al. 1998; Fernando et al. 2000). Taking these factors into account, the previous 1988 and 1982 analyses are in the range of variation of our analyses.

The FCA method was developed in the mid-1960s (Whitehead 1965) as an in-field evaluation of coconut variation before mite infestations had been reported and long before laboratory-based DNA fingerprinting became available, but its use has been validated by Zizumbo et al. (2005). Consistency was found between patterns of morphological variation of fruit ex situ and in situ, and those obtained using iso-enzymatic and molecular characteristics. They concluded that morphological characterization of the coconut fruit in situ is useful to estimate its genetic variability because of its simplicity, speed and ease of application in the field and in remote areas.

In another study (Gunn et al., Unpublished data), one of the authors (LB) identified a group of 6 "diagnostic" alleles, whose frequencies present a sharp contrast between the Indo-Atlantic coconuts (originating from South Asia) and the Pacific coconuts (originating from a region spanning from SouthEast Asia to Papua New Guinea). In the Indian Ocean, the frequencies of these alleles can be combined to calculate an "introgression index", which represents the proportion of the genome of a coconut, inherited from South-East Asian coconuts, which accompanied the austronesian migrations to Madagascar and to the Comoros, probably around the 6th or $7^{\text {th }}$ Century AD (Allibert 2008).

$\mathrm{R}^{2}$ is the coefficient of determination of the regression of the allele frequency on the multiallele introgression index. This index is the 
Table 1. Fruit Component Analysis for the local Tall and for other varieties

\begin{tabular}{|c|c|c|c|c|c|c|c|}
\hline & $\begin{array}{c}\text { Whole } \\
\text { fruit } \\
\mathrm{g}\end{array}$ & $\begin{array}{c}\text { Nut } \\
\mathrm{g}\end{array}$ & $\begin{array}{c}\text { Husk } \\
\mathrm{g}\end{array}$ & $\begin{array}{c}\text { Husk/ } \\
\text { fruit } \\
\%\end{array}$ & $\begin{array}{c}\text { Shell/ } \\
\text { nut } \\
\%\end{array}$ & $\begin{array}{c}\text { Kernel/ } \\
\text { nut } \\
\%\end{array}$ & $\begin{array}{c}\text { Water/ } \\
\text { nut } \\
\%\end{array}$ \\
\hline \multicolumn{8}{|c|}{ Analyses performed in Oman on 175 individuals from 25 sites } \\
\hline Mean & 1627 & 557 & 1073 & 62.6 & 29.7 & 44.5 & 25.8 \\
\hline SD & 684 & 179 & 594 & 11.7 & 5.3 & 10.0 & 11.4 \\
\hline $\mathrm{CV}$ & $42 \%$ & $32 \%$ & $55 \%$ & $19 \%$ & $18 \%$ & $22 \%$ & $44 \%$ \\
\hline Between site $\mathrm{R}^{2}$ & 0.422 & 0.334 & 0.439 & 0.503 & 0.262 & 0.448 & 0.448 \\
\hline Significance & $* * *$ & $* * *$ & $* * *$ & $* * *$ & $* *$ & $* * *$ & $* * *$ \\
\hline \multicolumn{8}{|c|}{ Previous analyses in Oman } \\
\hline \begin{tabular}{|l|} 
Landell Mills \\
Associates Ltd (1989)
\end{tabular} & 1314 & 620 & 694 & 52.5 & 29.5 & 48.7 & 21.9 \\
\hline Darweish 1982 & 1041 & 563 & 478 & 45.9 & 33.0 & 51.9 & 15.1 \\
\hline \multicolumn{8}{|c|}{ South Asia, Africa and the Caribbean } \\
\hline India & 1360 & 590 & 770 & 56.6 & 29.2 & 51.3 & 19.5 \\
\hline Sri Lanka & 1430 & 635 & 795 & 55.6 & 29.6 & 49.8 & 20.6 \\
\hline West African & 1041 & 558 & 483 & 46.4 & 29.0 & 54.2 & 16.8 \\
\hline \multicolumn{8}{|c|}{ South East Asia and the Pacific } \\
\hline Philippines & & & & & & & \\
\hline $\begin{array}{l}\text { Tagnanan Tall } \\
\text { Indonesia }\end{array}$ & 1671 & 1299 & 372 & 22.3 & 21.6 & 43.3 & 35.1 \\
\hline Java Tall & 1155 & 761 & 394 & 34.1 & 20.0 & 51.0 & 29.0 \\
\hline Borneo Tall & 1450 & 987 & 463 & 31.9 & 17.4 & 45.0 & 37.6 \\
\hline Malaysia & & & & & & & \\
\hline Malayan Tall & 1653 & 1067 & 586 & 35.5 & 22.4 & 45.5 & 32.1 \\
\hline Thailand & 1893 & 1305 & 589 & 31.1 & 21.1 & 42.7 & 36.1 \\
\hline Tahiti & 1285 & 817 & 468 & 36.4 & 24.5 & 53.2 & 22.3 \\
\hline
\end{tabular}

Darweish (1982) analyses appear to be based on the same observations as those used by previous consultants (HFAS 1976).

Table 2. Frequencies of 6 diagnostic alleles in Oman

\begin{tabular}{|l|c|c|c|c|c|}
\hline \multicolumn{1}{|c|}{ Allele } & Indo-Atlantic & South-East Asia & Oman & Single Allele Index & $\mathrm{R}^{2}$ \\
\hline C12 167 & $89.5 \%$ & $0.6 \%$ & $63.4 \%$ & $29.4 \%$ & 0.82 \\
E12 174 & $89.0 \%$ & $2.3 \%$ & $33.3 \%$ & $64.2 \%$ & 0.64 \\
A3 228 & $96.5 \%$ & $7.2 \%$ & $61.9 \%$ & $38.7 \%$ & 0.75 \\
F2 193 & $87.2 \%$ & $2.5 \%$ & $59.5 \%$ & $32.7 \%$ & 0.81 \\
E10 244 & $83.1 \%$ & $8.1 \%$ & $38.1 \%$ & $60.0 \%$ & 0.88 \\
C7 157 & $2.4 \%$ & $66.2 \%$ & $21.4 \%$ & $29.8 \%$ & 0.80 \\
\hline Index & $0.0 \%$ & $100.0 \%$ & $42.5 \%$ & & \\
\hline
\end{tabular}


mean of single-allele indices whose values are by definition equal to $0 \%$ in the non introgressed Indo-Atlantic populations and to $100 \%$ in SouthEast Asia.

The introgression index in Oman (42.5\%) is significantly higher than in the Seychelles $(2.8 \%)$ and in East Africa $(31.7 \%$, bilateral pairwise test $\mathrm{P}$-value $=0.033$ ) but lower than in Madagascar and in the Comoros (resp. $46.3 \%$ and 56.4\%). Due to its descent from two highly contrasting genetic origins, the Oman Tall has a high genetic polymorphism. The unbiased estimate of gene diversity (Nei, 1978) is 0.70, among the highest values found in coconut with the microsatellite kit. It is slightly higher than in the Comoros (0.67) and Madagascar (0.69). Typical values are 0.48 in South Asia Indo-Atlantic and 0.60 in south-East Asia.

\section{Imported varieties}

Recorded importations of coconuts, from 1983 to 1988 , are listed in table 3. One of the imported coconut varieties to Oman was identified during the survey as Sri Lanka Yellow Dwarf (SLYD) coconuts. This population was observed to be quite heterogeneous, with some palms growing faster than normal Dwarf with a bole formation at the base of the trunk similar to the ones growing at the Isolated Seed Garden in Ambakelle in Sri Lanka. Some of those dwarf palms in Oman produces big fruits and some small fruits and it is suggested that it should be investigated whether this difference is due to genetic or due to environment effect.

A red fruited coconut form, especially grown in farmers' fields, was also identified during the survey. These palms were identified as typical King Coconut, a semi tall coconut variety from Sri Lanka by visual observation. The results were verified by DNA analysis using molecular markers later. Three different forms of the King Coconut variety imported from Sri Lanka with oval, pointed and elongated (bottle shape) fruits were observed at the variety collection sites, in survey sites and in farmer's fields in fewer numbers. However some of those palms are looking like King Coconut but with a more pronounced dwarf habit. A red dwarf with oval fruits is also available both in variety collection and in survey sites. The DNA results confirmed that this variety is Malayan Red dwarf.

Two kinds of hybrids, the MAWA imported from Malaysia (similar to the PB121 developed in Côte d'Ivoire) and the CRIC65 (Sri Lanka Tall x Sri Lanka Green Dwarf or Sri Lanka Tall $x$ Sri Lanka Yellow Dwarf) developed in Sri Lanka which is locally named Kalim Bahim were also available in large numbers. The documents available in the office of the Salalah Research Centre indicated that about 25,000 CRIC65 seed nuts had been imported from Sri Lanka during 1983. The hybrid nature of these was proved by DNA analysis using molecular markers. The imported hybrids produce very well, often 150 to 200 nuts per palm per year under good management condition with drip irrigation. That has allowed the concerned farmers to produce at least $50 \%$ more coconut fruits than by planting local tall. It has been observed that farmers are using seed nuts from these high yielding hybrids for second generation planting. Several segregating progenies of hybrids were observed in many survey sites. This is a serious threat to the Oman coconut germplasm as contamination can occur between them and local coconut varieties.

In addition to those varieties, Tall coconut palms with ivory yellow fruits, inflorescences and peduncle can also be seen in the survey sites and in farmers' field in very few numbers mostly as solitary palms. They very much looked like the Gon Thembili variety from Sri Lanka. However there were no records of importation of Gon thembili from Sri Lanka to Oman. These palms may have arisen as a result of segregation due to cross-pollination from Oman local tall expressing rare alleles or as a mutant. These palms too should be sampled and planted in variety evaluation trials for further studies.

\section{Discussion}

\section{Ecological conditions}

The conditions for growing coconuts in the Southeastern Region of Oman are marginal in the extreme. Most other coconut growing countries depend on an annual average rainfall 
Table 3. Details of importation of coconut varieties to Oman

\begin{tabular}{|l|l|l|}
\hline \multicolumn{1}{|c|}{$\begin{array}{c}\text { Country } \\
\text { (date) }\end{array}$} & \multicolumn{1}{|c|}{ Varieties imported } & \multicolumn{1}{c|}{ Remarks } \\
\hline Sri Lanka (1983) & $\begin{array}{l}\text { 1. Sri Lanka Green Dwarf } \\
\text { 2. King Coconut } \\
\text { 3. Sri Lanka Yellow Dwarf } \\
\text { 4. Dwarf x Tall hybrid (locally named } \\
\text { as Kalim Bahim) }\end{array}$ & $\begin{array}{l}\text { Imported in very limited numbers and } \\
\text { planted in a variety block in the Salalah } \\
\text { Research Station }\end{array}$ \\
\hline Malaysia (1986) & $\begin{array}{l}\text { 1. Mawa hybrid } \\
\text { 2. Malaysia Yellow Dwarf }\end{array}$ & $\begin{array}{l}\text { Identified within the research station in } \\
\text { an experimental plot }\end{array}$ \\
\hline Sri Lanka & $\begin{array}{l}\text { 1. King Coconut } \\
\text { 2. CRIC65 (Tall x Green Dwarf) } \\
\text { 3. CRIC65 (Tall x Yellow Dwarf) }\end{array}$ & $\begin{array}{l}\text { King coconut and CRIC65 can be } \\
\text { identified both in Salalah Research } \\
\text { station and in Farmers' field }\end{array}$ \\
\hline $\begin{array}{l}\text { Sri Lanka } \\
\text { (September 1988) }\end{array}$ & $\begin{array}{l}\text { 1. Green Dwarf } \\
\text { 2. Yellow Dwarf }\end{array}$ & $\begin{array}{l}\text { Could be seen in Salalah Research } \\
\text { Station and in farmers' field }\end{array}$ \\
\hline
\end{tabular}

Figure 1. Fruits shapes and sections of some coconut palms from Oman (Photo R. Bourdeix)

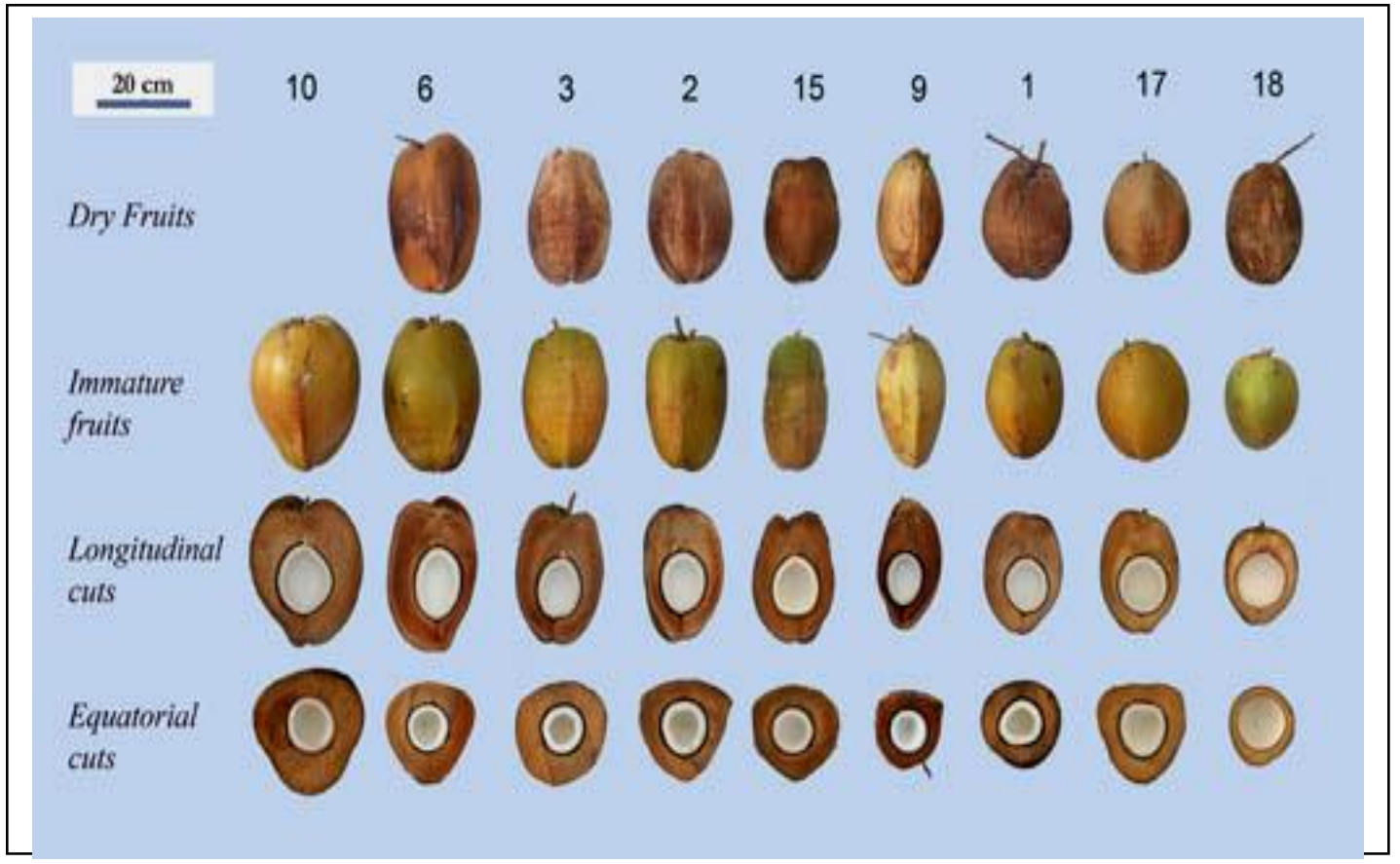


of not less than $1500 \mathrm{~mm}$ and yields start to suffer as soon as any period of dry weather begins to exceed 3 months. In Dhofar there are regularly 9 months of dry weather and the 3 month monsoon period delivers, on average, about $110 \mathrm{~mm}$ of rain. Yet coconuts grow naturally on the Salalah plain where their roots reach the fresh groundwater table. They grow well where irrigation is available, at least for the period of establishment and, preferably, throughout their economic cropping life. Irrigation with slightly saline water (conductance about 6000 umhos $/ \mathrm{cm}$ ) might be tolerated by coconuts in climates where seasonal rainfall is high enough to regularly flush the accumulated salts from the soil, in the Salalah region there is evidence that coconuts do not prosper if they are continually irrigated with saline water.

\section{Phenotypic characteristics of coconut in Dhofar}

Coconuts have grown in Dhofar for hundreds of years - when Ibn Battuta went there in $\mathrm{AD} 1330$ he reported that "they grow also betel-trees and coco-palms, which are found only in India and the town of Dhafari [Dhofar]" (Gibb 1929). The traditional variety, is thus well adapted to particularly harsh growing conditions in Oman, has similar fruit morphology and palm habit as those growing elsewhere in the Indian Ocean region, on the Atlantic coasts of Africa and South America and around the Caribbean. All of them share the following characteristics: a rather large number of oblong or angular fruit with thick husk (up to $70 \%$ fresh weight) and slow germination (more than 200 days); the nut inside the husk has a thick shell and 200-300g of mature endosperm, rich in oil and protein; the palm is quite precocious and the slow rate of leaf emission moderates its vertical growth and prolongs its bearing life; but they are generally highly susceptible to certain pests (e.g. mites) and lethal diseases.

Microsatellite markers confirm that the Oman coconuts are related to this group. Note that similar phenotypes with a high husk proportion in the fruit are also found on a number of Pacific atolls, but exhibit a totally different genetic background. But they are also genetically related to the coconuts from South- east Asia, whose fruits, rounded in shape, with a small percentage of husk and a large water to nut ratio, germinate quickly. The palm growth habit and other important traits also have a different morphology. In spite of large variations in size, this type is not seen in Oman and this contrasts with what is observed in Madagascar (Prudhomme 1906) or the Comoros (Bourdeix 2005).The difference might reflect selection for high fibre contents: this product was needed for ship building.

Both microsatellite marker (MM) and FCA data help to identify the probable origin of the Oman Tall as descended from two genepools. MM data locates the first in South Asia and the second in an area including South-East Asia and Papua (Lebrun et al. 2003). Not unexpectedly, these correspond to the Vavilov centres 2 and $2 \mathrm{a}$ (Vavilov 1935) and differ only slightly from the FCA based centres (Harries 1978; 1990; 1992). We suggest here that, prior to any human involvement; the genepool for wild coconuts began where coconuts with thick husk and slow germination were disseminated by floating between the beaches and islands of the Indian Ocean, probably extending into Pacific but not the Atlantic. Coconuts did not float to the Americas but Dhofar was within range. The second genepool represents the area where wild coconuts were domesticated (before being taken into cultivation worldwide). In fact, human interest in coconuts, particularly as a source of drinking water, must have begun with the first coastal journey out of Africa to Asia and Australasia. The domestication of coconut probably did not begin immediately because the first people in Australia did not plant it but other coastal communities might start using coir fibre to "sew" boats.

We suggest here that two gene pools developed as a result of domestication; one in South Asia and another in Malesia (a phytogeogaphical region between SE Asia and Australasia. Human involvement and interest in coconuts, particularly as a source of drinking water, must have begun with the first coastal journey out of Africa to Asia and Australasia. Eventually the coconut had so many useful properties it would be planted and cared for 
domestically and it has been suggested (Harries 2002) that this was on a relatively shallow continental shelf (part of an extensive inland area, linked to Asia during the ice ages when sea levels were lower). To this day the predominant coconuts in the South Indian group are 'wild' type and those in the Malaysian region are 'domestic' type."

The high degree of differentiation between these genepools today, as shown by MM suggests that they were separated long before the process of domestication was complete but it was just that which made introgression so important whenever and wherever the groups have come into contact. The MM data obtained in Dhofar and in the south-western Indian Ocean illustrate this process.

\section{Origin of the coconut in Oman}

Before the confrontation of molecular data with historical sources it is advisable review the optional alternatives, which are:

- That the coconut population of Dhofar may have predated the human population and established naturally, and perhaps been re-established more than once, by being carried from elsewhere in the region on the Somali Current, during the time of the strongest south-west monsoon.

- That there were no coconut palms until seednuts or seedlings were introduced, planted and maintained by human settlers, probably arriving by boat rather than overland and though still influenced by currents and monsoons, more likely to be selected or improved and from o outside the region.

This monsoon regime also favoured the intense trade activities that connected the Arabian Peninsula to India and further to the Far East during the late antiquity and the middle ages. Significantly, the Laccadive Islands were known to several Persian and Arabic writers as the "Diva Kambar" (the coir Islands Mohamed, 2005). The Laccadives and the Maldives were exporters of coir ropes and boat builders. In $\mathrm{AD} 1150$, al-Idrisi states that people from Oman and Marbat (Hadramaut), belonging to Yemen, came to the islands and cut the wood of the coconut palms and made ropes from the fibre of the palm with which they tied up the wood. They took this wood back to their own country and sold it or used it for different purposes (Mohamed 2002).

This trade also extended to East Africa, but an early introduction from this region is less likely. Schuilling and Harries (1990) note that the early history of coconut in East Africa remains uncertain and its establishment was a continuous affair extending over centuries. It was apparently not so abundant in the $14^{\text {th }}$ Century; otherwise Ibn Battuta would not have written that "coco-palms are found only in India and the town of Dhafari". In fact, he had previously visited Monbasa and Kilwa, mentioning locally produced and imported food, but not coconut. Werth (1933) notes that coconut in East Africa is always associated with human settlement, which suggests that most coconut populations in this region were still relatively recent.

However, south-east Asian alleles indicate that, the present time coconut in Oman shares ancestors with those in East Africa and in the Islands of the South-Western Indian Ocean, namely those introduced in Madagascar by the Austronesians. This is supported by the ancient presence of Oman in East Africa and in the Comoros. Seyyid Said, Sultan of Oman from 1806 to 1856 , even transferred his capital from Oman to Zanzibar and encouraged the settlement of Oman Arabs on the coast of East Africa (Krain et al. 2002) at a time when coir, copra and coconut oil began to be internationally traded. This south-east Asian genetic component represents more than $4 / 10$ of the genome, showing that importations were massive. This could mean that this new coconut type was appreciated or - possibly - more adapted to the harsh climatic conditions prevailing in Oman in the last few centuries. Such an adaptation, if confirmed, could be exploited in future drought resistance breeding programs. 


\section{Conclusion}

Although the local Oman Tall has similar phenotypic characteristics to other coconuts in South Asia, East and West Africa, the Caribbean and the Atlantic coast of South America a double origin is indicated. The initial population seen by Ibn Battuta originated from South Asia, but was considerably enriched (and at least partly replaced) by the importation of coconuts with a South-East Asian origin, via Madagascar, the Comoros and East Africa.

The substantial genetic contribution of the South-East Asian coconuts revealed by microsatellite markers was initially a surprise but is well understood when placed in the context of the broad exchanges that have taken place in the Indian Ocean (and beyond) for many centuries.

Coconuts in Oman today are testimony to a long history of migration and trade in the Western Indian Ocean, with Austronesian, African [Bantu], Arab, Indian [Tamil] and European participants. However, although the possibility that they established themselves naturally at an earlier period appears more difficult to demonstrate, it should not be discounted. Coconut culture in the Dhofar region perpetuates a long-standing local tradition. Its high genetic diversity represents a precious resource for plant breeders, which needs to be safeguarded and exploited. For example, the only local varieties, which seem to resist LY in Africa, are from Northern Tanzania (Kullaya and M'punami 2008; Baudouin et al. 2009). One may wonder whether they inherit their resistance from the South-East Asian ancestors they share with the Oman coconuts? Testing the Oman germplasm in Mozambique or in Tanzania and including it in breeding programmes may contribute to increasing the genetic diversity in resistant varieties, which is a warrant of durable resistance. Given their ability to strive in harsh environmental conditions, their use in drought resistance breeding programs may also be considered. On the other hand, Oman would certainly benefit from importing selected varieties, especially for the purpose of producing drinking nuts.
The recent revival of scientific research on the coconut palm in Oman is a good opportunity to strengthen the coconut sector. Importations of coconut varieties conducted in the 1980's were successful. Yellow Dwarf, Green Dwarf and King Coconut varieties are now widely available in Salalah city; Dwarf $\mathrm{x}$ Tall coconut hybrids produces indeed more fruits than local Tall coconut palms. However importation of new germplasm should be associated with a rational program of conservation and breeding of both traditional and imported varieties. Some isolated plantations form a kind of "islets in the desert". They can be used as conservation and seed production units, by maintaining the reproductive isolation of the coconut varieties conserved there (Bourdeix et al. 2008; 2009).

\section{Acknowledgements}

The authors wish to thank Oman Government through the Directorate General of Agricultural and Livestock Research and the Agricultural and Fisheries Development Fund for providing funds. They also wish to extend their gratitude to the Management and Scientists of the Salalah Research Station, for the excellent support, cooperation and friendship offered by them during the study tour in Oman.

\section{References}

Allibert C (2008) Austronesian migration and the establishment of the Malagasy civilisation: Contrasted readings in linguistics, archaeology, genetics and cultural anthropology. Diogenes 55(2): 716

Baudouin L, Lebrun P (2002) The development of a microsatellite kit and dedicated software for use with coconuts. Burotrop Bulletin (17): 16-20

Baudouin L, Philippe R, Quaicoe RN, Dery SK, Dollet M (2009) General overview of genetic research and experimentation on coconut varieties tolerant/resistant to lethal yellowing. OCL Oléagineux Corps Gras Lipides 16(2): 127-131 
Bourdeix R, Bambridge T, Larue S (2007) Islets save coconut: coconut: from an old Polynesian practice to the new concept of a crop gene bank located on smallest islands. International Journal of Island affairs 16(1): 4-57

Bourdeix R, Konan JL, N'Cho YP (2005) Coconut. A guide to traditional and improved varieties. Montpellier, France, Editions Diversiflora, 104 p.

Bourdeix R, George ML, Baudouin L, Joly HI, Guarino L, Engels J (2009) The concept of "Networked collection" or "Virtual collection": New developments and their applications to the conservation of the Coconut palm. In: Abstracts of paper presented at the 2nd European Congress of Conservation Biology, 1-5 September 2009, Prague, Czech Republic. Available on-line at: http://www.eccb2009.org/ uploads/book ofabstracts errata.pdf

Darweish (1982) A survey into the Feasibility of Establishing Coconut Plantations in Dhofar. Cited by: Landell Mills Associates Ltd (1989) Establishment of viable coconut industry in Salalah plain: Feasibility study. Final Report. Ministry of Agriculture and Fisheries, Sultanate of Oman

Fernando LCP, Wickaramananda IR, Aratchige NS (2000) Status of coconut mite, Aceria guerreronis, in Sri Lanka. In: Fernando LCP, de Moraes GJ and Wickaramananda IR (eds.), Proceedings of the international Workshop on Coconut mite (Aceria guerreronis), Coconut Research Institute, Sri Lanka, 6-8 January 2000, pp. 1-8

Gibb HAR (1929) Ibn Battuta, Travels in Asia and Africa 1325-1354., London: Broadway House, London

Harries HC (1978) The evolution, dissemination and classification of Cocos nucifera $\mathrm{L}$. The Botanical Review 44(3): 266-319

Harries HC (1981) Germination and taxonomy of the coconut palm. Ann. Bot. 48: 873883.
Harries HC (1990) Malesian origin for a domestic Cocos nucifera. In: Baas P. Kalkman K and Geesink R (Eds.) The Plant Diversity of Malesia, Kluwer, Dordrecht, The Netherlands

Harries HC (1992) The biogeography of the coconut palm. Principes 36: 55-62

Harries HC (2002) The "Niu" Indies: long lost "home" of the coconut. Palms 46(2): 97100

HFAS (1976) Development of coconut Plantings on $\mathrm{H}$ M the Sultan's Estate at Razat, Harrison Fleming Advisory Services. Cited by: Landell Mills Associates Ltd (1989) Establishment of viable coconut industry in Salalah plain: Feasibility study. Final Report. Ministry of Agriculture and Fisheries, Sultanate of Oman

Julia JF, Mariau D (1979) Nouvelles recherches en Côte d'Ivoire sur Eriophyes guerreronis (K.), acarien ravageur des noix du cocotier. Oléagineux 34: 181-187

Krain E, Issa JA, Kullaya A, Schuiling M, Harries HC (2002) The Natural and Economic History of the Coconut in Zanzibar. The Palm Enthusiast (Journal of the South African Palm Society) 19 (2): 720

Kullaya AK, Mpunami AA (2008) Breeding for Resistance to Coconut Lethal Disease in Tanzania In: Proceedings of the International Workshop on Lethal Yellowing Diseases on Coconut Accra, Ghana, 3-6 June 2008, 113-124

Landell Mills Associates Ltd (1989) Establishment of viable coconut industry in Salalah plain: Feasibility study. Final Report. Ministry of Agriculture and Fisheries, Sultanate of Oman

Lebrun P, N'Cho YP, Bourdeix R, Baudouin L (2003) Coconut. In: Hamon P, Seguin M., Perrier X and Glaszmann JC (eds) Genetic diversity of cultivated tropical plants. Cirad, Montpellier 
Mariau D (1977) Aceria guerreronis: un important ravageur des cocoteraies africaines et américaines. Oléagineux 32: 101-111.

Martinez RT, Baudouin L, Berger A, Dollet M (2010) Characterization of the genetic diversity of the tall coconut (Cocos nucifera L.) population by molecular markers microsatellite (SSR) types in the Dominican Republic. Tree Genetics and Genomes 6: 73-81.

Mohamed N (2002) Pre-Islamic Maldives. Man and Environment Journal of the Indian Society for Prehistoric and Quaternary Studies 27(1): 109-116

Mohamed N (2005) Maldivian Seafaring in the Pre-Portuguese Period. Paper presented at the 10th International Conference on Sri Lanka Studies, University of Kelaniya, Sri Lanka, 16-18 December 2005

Mohamed N (2005). Maldivian Seafaring in the Pre-Portuguese Period. Available on line at: http://www.qaumiyyath.gov.mv/docs/ whitepapers/history/seafaring.pdf. Cited 3 June 2010

Moore D, Alexander L, Hall RA (1989) The coconut mite, Eriophyes guerreronis Keifer in St. Lucia: yield losses and attempts to control it with acaricide, polybutene and Hirsutella fungus. Tropical Pest Management 35: 83-89

Santos GA, Batugal PA, Othman A, Baudouin L, Labouisse J-P. (1996) Manual on standardized research techniques in coconut breeding. IPGRI, Rome.

Sathiamma B, Radhakrishnan Nair, Koshy PK (1998) Outbreak of nut infesting eriophyid mite Eriophyies guerreronis (K.) in coconut plantations in India. Indian Coconut Journal 29: 1-3

Schuilling M, Harries HC (1990) The coconut Palm in East Africa. 1. East African Tall. Principes 38(1): 4-11

Shammas MI and Jacks G (2008) Management of the Salalah plain aquifer, Oman. In:
Bhattacharya P (Ed.) ground water for sustainable Development, CRC Press, Taylor and Francis. print ISBN: 978-0415-40776-2

Vavilov NI (1935) The Phytogeographical Basis for Plant Breeding, Volume I, Moscow, In: Vavilov NI, Love D (eds.), Origin and Geography of Cultivated Plants. Cambridge University Press, Cambridge

Vosmer T (1997) Indigenous fishing craft of Oman. The International Journal of Nautical Archaeology 26(3): 217-235

Werth E (1933) Distribution, Origin and Cultivation of the Coconut Palm. Ber. Deutschen Bot. Ges. 51, 301-304

Whitehead RA (1966) Sample survey and collection of coconut germplasm in the Pacific islands (30 May - 5 September 1964). Ministry of Overseas Development. HMSO, London

Zizumbo-Villarreal, D, Fernández-Barrera $\mathrm{M}$, Torres-Hernández N, ColungaGarcíaMarín P (2005) Morphological variation of fruit in Mexican populations of Cocos nucifera L. (Arecaceae) under in situ and ex situ conditions. Genetic Resources and Crop Evoution. 52: 419432 